\title{
Different patterns of climate change scenarios for short-term and multi-day precipitation extremes in the Mediterranean
}

Jan Kyselý* (1, 2), Santiago Beguería (3), Romana Beranová (1, 2), Ladislav Gaál (1, 4), Juan Ignacio López-Moreno (5)

(1) Institute of Atmospheric Physics AS CR, Prague, Czech Republic

(2) Dept. of Applied Mathematics, Technical University Liberec, Czech Republic

(3) Estación Experimental de Aula Dei, EEAD-CSIC, Zaragoza, Spain

(4) Dept. of Land and Water Resources Management, Slovak University of Technology, Bratislava, Slovakia

(5) Instituto Pirenaico de Ecología, IPE-CSIC, Zaragoza, Spain

* Corresponding author's address:

Jan Kyselý, Institute of Atmospheric Physics AS CR, Boční II 1401, 14131 Prague 4, Czech Republic; email: kysely@ufa.cas.cz

\begin{abstract}
The study examines climate change scenarios of precipitation extremes over the western, central and part of the eastern Mediterranean region for the late 21st century (2070-99) in an ensemble of high-resolution regional climate model (RCM) simulations from the ENSEMBLES project. Precipitation extremes are considered at a wide range of time scales from hourly to multi-day amounts and in individual seasons (DJF, MAM, JJA, SON). We focus on (i) dependence of the results on the time scale of precipitation aggregation, (ii) seasonal differences, (iii) uncertainties of the scenarios related to differences amongst the
\end{abstract}


RCM simulations, and (iv) identification of regions and seasons in which the projected changes in precipitation extremes are particularly large and/or robust in the RCM ensemble.

The examined ensemble of RCM simulations captures basic precipitation patterns for the recent climate (1961-90), including seasonal changes. Climate change scenarios for the late 21 st century differ substantially for short-term (hourly) and multi-day (5-day and 15-day) precipitation extremes, mainly in the western Mediterranean. Projected increases in short-term extremes exceed those of daily and multi-day extremes, and occur even in regions and seasons in which mean precipitation is projected to decline. This change in the patterns of extreme precipitation may have important hydrological consequences, with increases in the severity of flash floods in a warmer climate in spite of the overall drying projected for the region. However, uncertainty of the scenarios of precipitation extremes related to within-ensemble variability is large. Consistency of the projected changes amongst the RCMs is highest in winter and lowest in summer, and generally it is higher for short-term than multi-day extremes.

Key words: climate change - precipitation extremes - regional climate models - extreme value analysis - Mediterranean

\section{Introduction}

Heavy precipitation events are associated with major negative consequences for human society, particularly as they may trigger floods and landslides. There is also concern that their frequency and/or intensity increases in a warmer climate as the hydrologic cycle becomes more intense (Trenberth et al. 2003), even in areas and seasons in which mean precipitation is projected to decline (IPCC 2007).

One such area in which precipitation extremes have major impacts is the Mediterranean (Beaulant et al. 2011; Tramblay et al. 2012). Although previous studies have indicated that heavy precipitation is projected to increase in many parts of Europe in Global Climate Model (GCM) as well as Regional Climate Model (RCM) simulations under increased greenhouse gas concentrations (Frei et al. 2006; Buonomo et al. 2007; Fowler et al. 2007; Kharin et al. 2007; Goubanova and Li 2007; May 2008; Kyselý and Beranová 2009; Boberg et al. 2009; Fowler and Ekström 2009; Hanel and Buishand 2011, 2012; Kyselý et al. 2011a; Nikulin et al. 2011), little attention has been given to different time scales of precipitation extremes and 
the seasonal resolution of the projected changes. The Mediterranean is of particular interest because climate models project substantial drying in this area (in terms of mean precipitation and drought indices; e.g. Giorgi and Lionello 2008), which has been reported as one of the most robust features of current GCM simulations (Orlowsky and Seneviratne 2012), while the model projections are less conclusive as to changes in heavy precipitation. Possible future changes in hydrological patterns and water resources availability in this densely populated region may have dramatic societal and environmental effects (e.g. Garcia-Ruiz et al. 2011).

Precipitation extremes have different hydrological impacts depending on the duration of events: while short-term extremes (sub-daily, represented by hourly amounts in the present study), often due to convective storms, may be evaluated as proxies for flash floods, multi-day precipitation extremes are often considered proxies for large-scale floods in climate model outputs (e.g. Christensen and Christensen 2003; Pal et al. 2004; Gao et al. 2006; Hanel and Buishand 2011). Both these types of events may have disastrous environmental and socioeconomic consequences, but most previous studies dealing with the simulation of precipitation extremes and their scenarios in climate models evaluated durations of only one or more days. Shorter time scales are often more relevant for practical purposes and applications concerning hydrological extremes (e.g. Borga et al. 2011) than are daily and multi-day data, and that is why the current study involves also hourly precipitation extremes in addition to daily and multi-day amounts.

With respect to the seasonal resolution, studies evaluating scenarios of precipitation extremes usually focus on annual data or deal with summer and winter seasons separately. In large parts of the western and central Mediterranean, however, heavy precipitation events are most frequent and severe in autumn (Doswell et al. 1998; Jansa et al. 2000), and little attention has been devoted to autumn precipitation extremes in this area in recent climate model simulations.

Both these issues, i.e. scenarios of precipitation extremes on different time scales of precipitation aggregation and the seasonal dependence of the scenarios, are addressed in the present study. We examine climate change scenarios of 1-hour, 1-day, 5-day and 15-day precipitation extremes in high-resolution RCM simulations from the EU-FP6 ENSEMBLES project (see Section 2), separately in individual seasons (DJF, MAM, JJA and SON). From a viewpoint of practical applications, it is important to refine projections of how extreme rainfall distributions and design values may change within the planning horizon for system design (typically $\sim 20-100$ years; Ekström et al. 2005). Therefore, we focus on a relatively 
high quantile of distributions of precipitation extremes, corresponding to 50-yr return period, and its projected changes for the late 21 st century (2070-99).

The paper is organized as follows: The data and methods used are described in Section 2; the results (evaluation of basic precipitation patterns in the recent climate and climate change scenarios of precipitation extremes) are presented in Section 3; and the most important findings and their implications are discussed in Section 4.

\section{Data and methods}

\subsection{Data}

Regional climate models (RCMs) are the tools used most frequently for simulating climate change scenarios at subcontinental and regional levels (IPCC 2007). This is because the coarse grid scale of GCMs has severe limitations with respect to the representation of orography, land-sea distribution, and mesoscale processes. RCMs are driven by outputs from a GCM with a coarser resolution and allow for regional details and local peculiarities to be captured.

In this study, we examine 12 high-resolution $\left(0.22^{\circ}\right.$, corresponding approximately to $\left.25 \mathrm{~km}\right)$ RCM simulations from the ENSEMBLES project (http://ensembles-eu.metoffice.com/; van der Linden and Mitchell 2009). This ensemble includes 7 RCMs driven by 4 different GCMs. Basic information on the RCMs under study and their driving models is given in Table 1. A more detailed description and further references can be found in, for example, Christensen et al. (2008) and Sanchez-Gomez et al. (2009). Driving GCMs for the RCM simulations are the Max Planck Institute ECHAM5 model (Roeckner et al. 2003), the Hadley Centre model HadCM3 (Johns et al. 2003; 3 ensemble members with low, normal and high climate sensitivity), the Bergen Climate Model BCM (Furevik et al. 2003), and Arpege developed at Météo-France (Déqué et al. 1994).

Abilities of the RCMs to reproduce observed heavy precipitation patterns over Europe and their applicability in constructing climate change scenarios have been assessed in several previous studies (Boberg et al. 2009; Lenderink 2010; Herrera et al. 2010). Many observed characteristics of extremes are well simulated by the RCMs, although differences exist in how the models perform (van der Linden and Mitchell 2009; Lenderink 2010). The ensemble 
means usually produce much better results than does a single RCM (Herrera et al. 2010), and that is why we focus on ensemble-mean patterns over the 12 RCMs in this study as well.

Climate change scenarios are evaluated for the late 21st century (2070-99) with respect to the control period 1961-90. An exception is made for the CLM RCM, for which only 21-yr period 2070-90 is taken for the scenario, due to errors and missing data after 2090. The projected climate change is expressed as per cent change relative to the control climate. All scenarios are taken as time slices from transient runs under the SRES A1B emission scenario (IPCC 2007).

\subsection{Methods}

For estimation of high quantiles of precipitation amounts (corresponding to 50-yr return values), the Generalized Extreme Value (GEV) distribution (Coles 2001) is fitted to samples of seasonal maxima for 1-hour, 1-day, 5-day and 15-day precipitation amounts, using the method of L-moments (Hosking and Wallis 1997). The GEV distribution is the limiting distribution of maxima with theoretical justification (Fisher and Tippett 1928), and it is widely applied also in modelling precipitation extremes, including climate model studies (Buonomo et al. 2007; Goubanova and Li 2007; Kyselý et al. 2011a; Hanel and Buishand 2011, 2012).

The $90 \%$ confidence intervals (CIs) of the estimated high quantiles of the GEV distribution in individual RCMs and gridboxes were obtained using analytical formulae based on asymptotic approximation (Sec. 7.1.3, Rao and Hamed 1999). In these formulae, the standard error $s_{T}$ of the $T$-year quantile $x_{T}$ is estimated as a function of the parameter estimates of the GEV distribution and the return period $T$. Then, an approximate (1- $\alpha)$ confidence interval for $x_{T}$ is given by $x_{T} \pm t_{\alpha / 2} s_{T}$ where $t$ is the standard normal variate (Eq. 4.4.2, Rao and Hamed 1999).

\section{Results}

\subsection{Reproduction of basic precipitation patterns in the control RCM outputs}

Although the present study does not focus in detail on validating precipitation characteristics in control RCM simulations, we briefly present a comparison of basic precipitation patterns in the ensemble of control RCM outputs (1961-90) against the E-OBS gridded dataset (Haylock et al. 2008; data available over land only). 
Fig. 1 shows spatial patterns of mean seasonal precipitation and mean seasonal maxima of 1day and 5-day precipitation amounts in the observed data (E-OBS); black dots denote those gridboxes in which annual maximum of a given precipitation characteristic occurs in a given season. In large parts of the western and central Mediterranean, highest 1-day and 5-day precipitation amounts are observed in autumn, when sea surface temperatures are still high from summer heating while the onset of autumn increases the chances for strong synoptic forcing (Doswell et al. 1998). To a smaller extent, this pattern holds also for mean seasonal precipitation (Fig. 1). Only in the Balkan region, maxima of precipitation extremes occur in summer, and in the western part of the Iberian Peninsula, southern Greece and western Turkey, they are seen in winter.

While the ensemble-mean spatial patterns (averaged over the $12 \mathrm{RCMs}$ ) of precipitation characteristics for the recent climate (1961-90; Fig. 2) show many similar features, there are also conspicuous differences. The RCMs reproduce the basic feature that precipitation extremes are most severe in autumn in large parts of the Mediterranean. However, this encompasses not only the western and central Mediterranean, as in the observed data, but also the Balkan region. The RCMs also capture that in the western part of the Iberian Peninsula and in southern Greece, precipitation extremes are most intense in winter. The precipitation extremes tend to be overestimated in the RCMs (Fig. 2) compared to E-OBS (Fig. 1), as has been reported in some previous RCM-evaluation studies (e.g. Lenderink 2010), but it is not entirely clear to what extent this behaviour is related to model errors and to what extent it is due to over-smoothing of precipitation extremes in the E-OBS dataset (cf. Hofstra et al. 2009).

The spatial patterns of precipitation amounts, seasonal differences, effects of orography as well as the north-south gradients are reproduced reasonably well in the ensemble mean (Fig. 2). Differences with respect to observation become larger for individual RCM control simulations, but all 12 RCMs agree on the fact that precipitation extremes are most intense during autumn in most of the western and central Mediterranean (Fig. 3). This is an important finding and supports the credibility of the RCM-simulated precipitation patterns.

\subsection{Scenarios of changes in precipitation extremes for the late 21st century (2070-99)}

Fig. 4 depicts ensemble-mean projected changes in mean seasonal precipitation and mean seasonal maxima of 1-hour to 15-day precipitation. Gridboxes in which at least 9 out of the 12 RCMs agree on a given sign of change are indicated by black dots. 
For mean seasonal precipitation (Fig. 4, left column), the RCMs project decreases in all seasons except for the northern parts of the Mediterranean in winter (the zero change latitude in winter corresponds approximately to $40^{\circ} \mathrm{N}$ ). The decreases are most pronounced in the western Iberian Peninsula in summer, and similar patterns appear in nearly all RCMs (not shown).

The patterns are different for mean seasonal maxima, particularly for short-term aggregations (Fig. 4). Increases clearly prevail for maxima of 1-hour precipitation, except for summer, while declines are characteristic for 15-day precipitation maxima. The projected changes are close to zero for maxima of 1-day and 5-day precipitation if averaged over the region (they are within $-10 \%$ to $+6 \%$ also in all regions and seasons evaluated in Table 2). Note that in summer increases appear in parts of the western Mediterranean (the Alboran and Balearic seas) for short-term extremes, despite substantial declines in mean seasonal precipitation.

For the 50-yr return values, the RCM ensemble-mean patterns yield widespread increases for 1-hour precipitation, with high consistency amongst the RCMs (marked by black dots) in winter, spring and autumn (Fig. 5). Increases prevail for 1-day precipitation in all seasons, too, and for 5-day and 15-day precipitation in all seasons except summer. Declines for 5-day and 15-day precipitation in summer are projected mainly in the Iberian Peninsula and Greece (cf. Table 2).

Although generally the expected change in mean seasonal maxima is noticeably lower than for the 50-yr return period, the main findings do not depend on the particular choice of the high quantile of precipitation distributions. Thus, very similar results are found for the $20-\mathrm{yr}$ and 100-yr return values (not shown).

Table 2 summarizes ensemble-mean projected changes of precipitation characteristics in the 5 individual regions depicted in Fig. 6. Since the interest in precipitation extremes concerns floods over land and simulated precipitation may have larger biases over oceanic than land areas (particularly as to convective precipitation in autumn, cf. Funatsu et al. 2009), the statistics are calculated over land areas only in most regions. The exception is region b2 (Balearic Sea) where the extent of land areas is small but precipitation extremes are still of high importance, so both oceanic and land gridboxes were considered in this region. Increases in 1-hour precipitation maxima are found in both characteristics (mean seasonal maxima, 50yr return values) in all regions and seasons except for the Iberian Peninsula and Greece in summer. The increases in hourly precipitation extremes are always (in all regions and seasons) larger than those in 1-day and multi-day extremes. The largest ensemble-mean 
increases in the 50-yr return precipitation are projected for winter and autumn over the Iberian Peninsula and for autumn in the other 4 regions. This may be of particular relevance for the design of structures and flood-protection measures, since already in the present climate autumn is the season with most severe precipitation extremes in all examined regions (cf. Figs. 1 and 2).

\section{Discussion}

\subsection{In which regions and seasons are the projected changes in precipitation extremes largest and most robust?}

For short-term precipitation extremes, the RCMs project large increases in the entire Mediterranean in all seasons except for summer, with high consistency among the RCMs (Fig. 5). For daily and multi-day extremes, the pattern of increases is robust within the examined ensemble in winter, and in the central Mediterranean also in autumn. In other seasons and areas, the consistency amongst the RCMs is lower, and it tends to decline for longer aggregations (multi-day amounts).

If uncertainties are evaluated by plotting a measure of the range of values projected by individual ensemble members (at the gridbox scale), the differences among the RCMs are pronounced even for short-term amounts. Fig. 7 shows the interquartile range of the projected changes of the 50-yr return values for 1-hour precipitation. Although increases prevail also for the $25 \%$ quantile (except in summer), the relative increases are rather small in some RCMs, and in some areas the $25 \%$ quantile of the distribution of projected changes is negative even in winter and autumn (Fig. 7).

Similar plots for the 50-yr return values of 5-day precipitation show different signs (colours) prevailing for the $25 \%$ and $75 \%$ quantiles of the distribution of projected changes in all seasons (Fig. 8). This illustrates that the uncertainty is rather large and different RCMs yield climate change scenarios that may substantially differ from each other. Given the large variability among the RCMs as well as large 'sampling fluctuations' of precipitation in space, scenarios of possible future changes in precipitation extremes, often required for other applications, should not be based on a single RCM simulation nor single gridbox data.

The relatively large within-ensemble variability of projected changes in the 50-yr return precipitation of different durations as well as pronounced sampling variability are demonstrated in Fig. 9 for the autumn season (when heavy precipitation is most frequent and 
intense in most of the Mediterranean). However, all 12 RCMs agree on two basic and robust patterns: (i) enhanced tendency to increases in precipitation extremes for shorter compared to longer durations (the patterns are greenest for 1-hour amounts in all RCMs), and (ii) larger relative increases in extremes (of any duration) than in mean autumn precipitation (for which drying prevails in most RCMs). There is no clear pattern of dependence of the results on the driving GCM.

The within-ensemble variability of precipitation characteristics in autumn is summarized in Fig. 10 in terms of box-plots of the projected changes in the 5 regions shown in Fig. 6 . The plots demonstrate that increases in the 50-yr return values are much larger than those in mean seasonal maxima in all regions, particularly for 1-hour precipitation, and that while the within-ensemble variability is pronounced for the 50-yr return values, it is nevertheless comparable to the within-ensemble variability of projected changes in mean autumn precipitation in most examined regions (except for Southern France and Greece).

\subsection{Different scenarios for short-term and multi-day precipitation extremes}

Comparison between projected changes of short-term (1-hour) and multi-day precipitation extremes, particularly in the tail of the distribution (50-yr return values), suggests that substantial differences may be expected between characteristics of possible future climate that are indicative of changes in flash floods and large-scale floods, respectively. This concerns mainly the western Mediterranean, as projected increases in short-term precipitation extremes are much larger than those of multi-day extremes in autumn and winter, and in spring and summer, there appear declines in multi-day extremes (Fig. 5). The sign of the projected change of short-term and multi-day precipitation extremes tends to be opposite over the Iberian Peninsula and the Alboran and Balearic seas in spring and summer.

This suggests considerable changes in precipitation patterns that will be manifested also in hydrological response. The intensity of short-term convective storms may increase in a warmer climate, even under the expected drying of the region at the annual and seasonal scale. Infiltration excess as consequence of short episodes of very intense precipitation is a very common mechanism of runoff generation in the Mediterranean, causing sudden flash flood events especially in first-order streams and semi-permanent ravines that are common in the region (García-Ruiz et al. 2008). Therefore, the frequency and magnitude of this kind of events may increase in a future climate. On the other hand, formation of cloud belts associated with multi-day intense precipitation may be reduced (see also Section 4.4). This will have 
implications for the occurrence of large-scale floods that are generated by prolonged and spatially wide-spread rainfall events, which may see a decrease. It may have a significant influence on the availability of water resources, too, since the occurrence of long-lasting rainfall events in winter and early spring is crucial for the infilling of reservoirs before the start of the dry season (García-Ruiz et al. 2011).

\subsection{Short-term precipitation extremes in climate models}

In contrast to daily and multi-day precipitation amounts, sub-daily precipitation data in climate models have rarely been validated against observations. This is mainly due to the lack of high-quality data series for sub-daily precipitation against which the simulated data may be evaluated. Hanel and Buishand (2010) showed that there might be large deviations from reality of simulated hourly precipitation extremes in RCMs, which may in turn raise questions as to the projected changes in these extremes. Their study was confined to a specific area (the Netherlands), however, and there is a clear need to enhance the scope of RCM validation studies to include also sub-daily precipitation data in other regions.

Moreover, only a small number of studies have dealt with climate change scenarios for shortterm precipitation extremes from climate model simulations (Grum et al. 2006; Lenderink and van Meijgaard 2008, 2010; Onof and Arnbjerg-Nielsen 2009; Olsson et al. 2009; Hanel and Buishand 2010). Although most of these studies dealt with only a single RCM, their results are broadly consistent with the findings reported in the present analysis for the Mediterranean. Of particular relevance are the conclusions of Lenderink and van Meijgaard (2008), who found that the projected increases in hourly precipitation extremes exceed those of daily precipitation extremes in the RACMO RCM. The present study complements the outlined framework that climate change may have larger effects on short-term precipitation extremes by analysing the ensemble of 12 RCM simulations and the wide area of the Mediterranean.

\subsection{Links between changing characteristics of Mediterranean cyclones and precipitation extremes in a warmer climate?}

The finding that projected changes in multi-day precipitation extremes are much smaller and less consistent than those of short-term extremes suggests that cyclones and atmospheric patterns causing heavy precipitation in the Mediterranean may become less persistent in a warmer climate. This appears to be in agreement with projected declines in cyclonic activity over the Mediterranean, reported in many climate change studies (e.g. Leckebusch et al. 2006; 
Bengtsson et al. 2006; Pinto et al. 2007). A review paper by Ulbrich et al. (2009) concluded that cyclonic activity in this area "will be apparently particularly affected by climate change" (Section 4.1.2). This is also in accord with projected changes of precipitation extremes in Central Europe, with less pronounced increases towards the east (Kyselý et al. 2011b), i.e. in a region where cloud belts associated with cyclones of the Mediterranean origin are more often conducive to flood-generating precipitation extremes.

However, most studies dealing with changes in cyclonic activity and storm tracks focus on winter, and increases have been reported over the Mediterranean in some models in summer (Löptien et al. 2008). Thus, the pattern of a possible future change may be more complex. This is even more apparent if one considers changes in the number of cyclones and their intensity, which are sometimes found to go in opposite directions in climate change projections (Musculus and Jacob 2005). Lionello et al. (2008) also reported an increase in the number of Mediterranean cyclones in summer but a significant reduction of storm track intensity over the Mediterranean region during late summer and autumn. The results are obviously dependent on climate model and large uncertainties in the future projections remain.

\section{Conclusions}

The main findings of the present study are as follow:

- The examined ensemble of RCM simulations reproduces basic precipitation patterns in the Mediterranean for the recent climate (1961-90) reasonably well, including seasonal differences.

- Climate change scenarios of precipitation extremes for the late 21st century (2070-99) differ for short-term (hourly) and multi-day amounts, mainly in the western Mediterranean. Projected increases in short-term precipitation extremes exceed those of multi-day extremes and occur even in regions and seasons in which mean precipitation is projected to decline.

- This change in precipitation patterns may be manifested also in the hydrological response, with increases in the severity of flash floods in a warmer climate. More intense short-term precipitation falling on a drier soil (due to declines in mean 
precipitation) with possibly reduced water infiltration capabilities (due to the effect of soil water repellency) may further exacerbate severity of flash floods.

- The largest ensemble-mean increases in precipitation extremes are projected in autumn over most of the Mediterranean. This may again be of particular importance for the design of structures and flood-protection measures, as autumn is the season with most severe precipitation extremes already in the present climate.

- Because uncertainty of the projected changes in precipitation extremes related to within-ensemble variability is large, future projections based on a single RCM (as evaluated in some studies) should be interpreted with caution. Nevertheless, all the RCMs examined agree on basic patterns concerning (i) enhanced tendency to increases in precipitation extremes for shorter compared to longer durations, and (ii) larger relative increases in extremes of any duration than in mean seasonal precipitation (for which declines prevail). Rather surprisingly, the within-ensemble variability of the projected changes in 50-yr return precipitation and in mean seasonal precipitation may be comparable if averaged over larger regions (such as the Iberian Peninsula).

- Consistency of the projected changes in precipitation extremes amongst the RCMs and different time scales of precipitation aggregation is highest in winter and lowest in summer, and generally it is better for short-term than multi-day extremes.

We emphasize that the RCM simulation domain does not include parts of the eastern and southeastern Mediterranean. Although the basic pattern of larger increases in short-term than multi-day precipitation extremes holds true over the whole domain, high-resolution RCM simulations over the southeastern Mediterranean are needed to complement recent studies for this region (e.g. Alpert et al. 2008; Samuels et al. 2011) and to yield additional insight into geographical extent of the pattern.

It should also be noted that the true uncertainty of climate change scenarios is in fact much larger than the spread of the examined RCMs. All simulations were run under a single SRES emission scenario (A1B; no similar ensemble for other emission scenarios is available at the same horizontal resolution), and the GCM-RCM matrix is quite incomplete: 6 RCMs were driven by HadCM3, 4 RCMs by ECHAM5, and only the 2 remaining RCMs by other GCMs (Arpege and $\mathrm{BCM}$ ). The range of uncertainties would likely increase considerably if a more complete ensemble of RCM simulations driven by a larger suite of GCMs and with a range of possible scenarios of the radiative forcing were available. However, some of the main findings of this work, such as tendency to larger increases in precipitation extremes for shorter 
compared to longer durations, are general within the ensemble and do not depend on the driving GCM.

While this study focused on statistical evaluation of precipitation extremes in the ensemble of high-resolution RCM simulations, better understanding of physical mechanisms behind the data is also needed. Follow-up work should address the role of changes in atmospheric circulation, including modes of variability such as the North Atlantic Oscillation (LópezMoreno et al. 2011), the Mediterranean Oscillation (Rodrigo 2010), and the Western Mediterranean Oscillation (Hidalgo-Muñoz et al. 2011), as well as that of large-scale circulation patterns conducive to heavy precipitation in the Mediterranean in modifying patterns of precipitation extremes in a warmer climate. Beaulant et al. (2011) found that the number of days with large-scale circulation patterns propitious to heavy precipitation in the Mediterranean increases significantly in their future climate simulations, which may contribute to the projected increases of extreme precipitation. Whether such behaviour is typical for a wide ensemble of RCM simulations remains an open question. Links between changes in precipitation extremes and cyclonic activity over the Mediterranean are another topic that deserves attention. Such further investigations would allow for complementing the presented results by physical insight into processes driving changes in the patterns of potentially disastrous heavy precipitation events in this area.

Acknowledgements: The study was supported by the Czech Science Foundation under project P209/10/2265 and by CGL2011-24185 financed by the Spanish Commission of Science and Technology (CICYT) and FEDER. Parts of the work were carried out during stay of the first author at Estación Experimental de Aula Dei, Zaragoza, Spain, funded by Consejo Superior de Investigaciones Científicas (CSIC) and the Czech Science Foundation. The research team benefited also through interactions within the KLIMATEXT project (CZ.1.07/2.3.00/20.0086) funded by the European Social Fund, and Grupo de Excelencia E68 financed by the Aragón Government and FEDER. The RCM and E-OBS data were produced by the EU-FP6 project ENSEMBLES (contract number 505539). Thanks are due to Z.Rulfová, Institute of Atmospheric Physics, Prague, for review of available literature on short-term precipitation in RCMs, and anonymous reviewers for comments on the original manuscript. 


\section{References}

Alpert P., Krichak S.O., Shafir H., Haim D., Osetinsky I., 2008. Climatic trends to extremes employing regional modeling and statistical interpretation over the E. Mediterranean. Global Planet. Change 63, 163-170.

Beaulant A.L., Joly B., Nuissier O., Somot S., Ducrocq V., Joly A., Sevault F., Deque M., Ricard D., 2011. Statistico-dynamical downscaling for Mediterranean heavy precipitation. Q. J. Roy. Meteor. Soc. $137,736-748$.

Bengtsson L., Hodges K.I., Roeckner E., 2006. Storm tracks and climate change. J. Climate 19, 35183543.

Boberg F., Berg P., Thejll P., Gutowski W.J., Christensen J.H., 2009. Improved confidence in climate change projections of precipitation further evaluated using daily statistics from ENSEMBLES models. Clim. Dyn. 35, 1509-1520. doi 10.1007/s00382-009-0683-8

Borga M., Anagnostou E.N., Blöschl G., Creutin J.-D., 2011. Flash flood forecasting, warning and risk management: the HYDRATE project. Environmental Science and Policy 14, 834-844.

Buonomo E., Jones R., Huntingford C., Hannaford J., 2007. On the robustness of changes in extreme precipitation over Europe from two high resolution climate change simulation. Q. J. Roy. Meteor. Soc. $133,65-81$.

Christensen J.H., Christensen O.B., Lopez P., van Meijgaard E., Botzet M., 1996. The HIRHAM4 regional atmospheric climate model. Scientific Report 96-4. DMI, Copenhagen.

Christensen J.H., Christensen O.B., 2003. Severe summertime flooding in Europe. Nature 421, 805806.

Christensen J.H., Boberg F., Christensen O.B., Lucas-Picher P., 2008. On the need for bias correction of regional climate change projections of temperature and precipitation. Geophys. Res. Lett. 35, L20709.

Coles S., 2001. An introduction to statistical modeling of extreme values. Springer-Verlag, London.

Déqué M., Dreveton C., Braun A., Cariolle D., 1994. The ARPEGE/IFS atmosphere model: a contribution to the French community climate modelling. Clim. Dyn. 10, 249-266.

Doswell C.A., Ramis C., Romero R., Alonso S., 1998. A diagnostic study of three heavy precipitation episodes in the Western Mediterranean region. Wea. Forecasting 13, 102-124.

Ekström M., Fowler H.J., Kilsby C.G., Jones P.D., 2005. New estimates of future changes in extreme rainfall across the UK using regional climate model integrations. 2. Future estimates and use in impact studies. J. Hydrol. 300, 234-251.

Fisher R.A., Tippett L.H.C., 1928. Limiting forms of the frequency distribution of the largest and smallest member of a sample. Proc. Cambridge Phil. Soc. 24, 180-190.

Fowler H.J., Ekström M., Blenkinsop S., Smith A.P., 2007. Estimating change in extreme European precipitation using a multimodel ensemble. J. Geophys. Res. 112, D18104.

Fowler H.J., Ekström M., 2009. Multi-model ensemble estimates of climate change impacts on UK seasonal rainfall extremes. Int. J. Climatol. 29, 385-416.

Frei C., Schöll R., Fukutome S., Schmidli J., Vidale P.L., 2006. Future change of precipitation extremes in Europe: Intercomparison of scenarios from regional climate models. J. Geophys. Res. 111, D06105. doi:10.1029/2005JD005965

Funatsu B.M., Claud C., Chaboureau J.-P., 2009. Comparison between the large-scale environments of moderate and intense precipitating systems in the Mediterranean region. Mon. Wea. Rev. 137, 3933-3959.

Furevik T., Bentsen M., Drange H., Kindem I.K.T., Kvamst N.G., Sorteberg A., 2003. Description and evaluation of the Bergen climate model: ARPEGE coupled with MICOM. Clim. Dyn. 21, 27-51.

Gao X., Pal J.S., Giorgi F., 2006. Projected changes in mean and extreme precipitation over the Mediterranean region from a highresolution double-nested RCM simulation. Geophys. Res. Lett. 33, L03706. doi:10.1029/2005GL024954 
García-Ruiz J.M., Regüés D., Alvera B., Lana-Renault N., Serrano-Muela P., Nadal-Romero E., Navas A., Latron J., Martí-Bono C., 2008. Plant cover, flood generation and sediment transport at catchment scale: a gradient of experimental catchments in the central Pyrenees. J. Hydrol. 356, 245-260.

Garcia-Ruiz J.M., Lopez-Moreno J.I., Vicente Serrano S.M., Lasanta-Martinez T., Begueria S., 2011. Mediterranean water resources in a global change scenario. Earth Science Reviews 105, 121-139.

Giorgi F., Bi X., Pal J., 2004. Means, trends and interannual variability in a regional climate change experiment over Europe. Part I: Present day climate (1961-1990). Clim. Dyn. 22, 736-756.

Giorgi F., Lionello P., 2008. Climate change projections for the Mediterranean region. Global Planet. Change 63, 90-104.

Goubanova K., Li L., 2007. Extremes in temperature and precipitation around the Mediterranean basin in an ensemble of future climate scenario simulations. Global Planet. Change 57, 27-42. doi:10.1016/j.gloplacha.2004.06.010

Grum M., Jørgsen A.T., Johansen R.M., Linde J.J., 2006. The effect of climate change on urban drainage: an evaluation based on regional climate model simulations. Water Sci. Technol. 54, 915. doi:10.2166/wst.2006.592

Hanel M., Buishand T.A., 2010. On the value of hourly precipitation extremes in regional climate model simulations. J. Hydrol. 393, 265-273. doi: 10.1016/j.hydrol.2010.08.024

Hanel M., Buishand T.A., 2011. Analysis of precipitation extremes in an ensemble of transient regional climate model simulations for the Rhine basin. Clim. Dyn. 36, 1135-1153. doi 10.1007/s00382-010-0822-2

Hanel M., Buishand T.A., 2012. Multi-model analysis of RCM simulated 1-day to 30-day seasonal precipitation extremes in the Czech Republic. J. Hydrol. 412-413, 141-150. doi:10.1016/j.jhydrol.2011.02.007.

Haylock M.R., Hofstra N., Klein Tank A.M.G., Klok E.J., Jones P.D., New M., 2008. A European daily high-resolution gridded dataset of surface temperature and precipitation. J. Geophys. Res. 113, D20119. doi:10.1029/2008JD10201.

Herrera S., Fita L., Fernández J., Gutiérrez J.M., 2010. Evaluation of the mean and extreme precipitation regimes in the ENSEMBLES RCM multi-model dataset over Spain. J. Geophys. Res. 115, D21117.

Hidalgo-Muñoz J.M., Argueso D., Gamiz-Fortis S.R., Esteban-Parra M.J., Castro-Diez Y., 2011. Trends of extreme precipitation and associated synoptic patterns over the southern Iberian Peninsula. J. Hydrol. 409, 497-511.

Hofstra N., Haylock M., New M., Jones P.D., 2009. Testing E-OBS European high-resolution gridded data set of daily precipitation and surface temperature. J. Geophys. Res. 114, D21101. doi:10.1029/2009JD011799

Hosking J.R.M., Wallis J.R., 1997. Regional Frequency Analysis. An Approach Based on L-moments. Cambridge University Press, Cambridge, New York, Melbourne.

IPCC, 2007. Climate Change 2007: The physical science basis. Contribution of Working Group I to the IPCC Fourth Assessment Report. Cambridge University Press, Cambridge.

Jacob D., 2001. A note to the simulation of the annual and inter-annual variability of the water budget over the Baltic Sea drainage basin. Meteorol. Atmos. Phys. 77, 61-73.

Jansa A., Genoves A., Garcia-Moya J.A., 2000. Western Mediterranean cyclones and heavy rain. Part 1: Numerical experiment concerning the Piedmont flood case. Meteorological Applications 7, $323-333$.

Johns T.C., Gregory J.M., Ingram W.J., Johnson C.E., Jones A., Lowe J.A., Mitchell J.F.B., Roberts D.L., Sexton D.M.H., Stevenson D.S., Tett S.F.B., Woodage M.J., 2003. Anthropogenic climate change for 1860 to 2100 simulated with the HadCM3 model under updated emissions scenarios. Clim. Dyn. 20, 583-612. 
Jones R.G., Noguer M., Hassell D.C., Hudson D., Wilson S.S., Jenkins G.J., Mitchell J.F.B., 2004. Generating high-resolution climate change scenarios using PRECIS. Met Office Hadley Centre, Exeter, UK.

Kharin V.V., Zwiers F.W., Zhang X., Hegerl G.C., 2007. Changes in temperature and precipitation extremes in the IPCC ensemble of global coupled model simulations. J. Climate 20, 1419-1444. doi: 10.1175/JCLI4066.1

Kyselý J., Beranová R., 2009. Climate change effects on extreme precipitation in central Europe: uncertainties of scenarios based on regional climate models. Theor. Appl. Climatol. 95, 361-374.

Kyselý J., Gaál L., Beranová R., Plavcová E., 2011a. Climate change scenarios of precipitation extremes in Central Europe from ENSEMBLES regional climate models. Theor. Appl. Climatol. 104, 529-542. doi 10.1007/s00704-010-0362-z

Kyselý J., Gaál L., Beranová R., 2011b. Projected changes in flood-generating precipitation extremes over the Czech Republic in high-resolution regional climate models. Journal of Hydrology and Hydromechanics 59, 217-227.

Leckebusch G.C., Koffi B., Ulbrich U., Pinto J.G., Spangehl T., Zacharias S., 2006. Analysis of frequency and intensity of winter storm events in Europe on synoptic and regional scales from a multimodel perspective. Clim. Res. 31, 59-74.

Lenderink G., van Meijgaard E., 2008. Increase in hourly precipitation extremes beyond expectations from temperature changes. Nat. Geosci. 1, 511-514. doi:10.1038/ngeo262

Lenderink G., 2010. Exploring metrics of extreme daily precipitation in a large ensemble of regional climate model simulations. Clim. Res. 44, 151-166.

Lenderink G., van Meijgaard E., 2010. Linking increases in hourly precipitation extremes to atmospheric temperature and moisture changes. Environ. Res. Lett. 5, 025208. doi 10.1088/17489326/5/2/025208

Lionello P., Boldrin U., Giorgi F., 2008. Future changes in cyclone climatology over Europe as inferred from a regional climate simulation. Clim. Dyn. 30, 657-671.

Lopez-Moreno J.I., Vicente-Serrano S.M., Moran-Tejeda E., Lorenzo-Lacruz J., Kenawy A., Beniston M., 2011. Effects of the North Atlantic Oscillation (NAO) on combined temperature and precipitation winter modes in the Mediterranean mountains: Observed relationships and projections for the $21^{\text {st }}$ century. Global Planet. Change 77, 62-76.

Löptien U., Zolina O., Gulev S.K., Latif M., Soloviov V., 2008. Cyclone life cycle characteristics over the northern hemisphere in coupled GCMs. Clim. Dyn. 31, 507-532.

May W., 2008. Potential future changes in the characteristics of daily precipitation in Europe simulated by the HIRHAM regional climate model. Clim. Dyn. 30, 581-603.

Musculus M., Jacob D., 2005. Tracking cyclones in regional model data: the future of Mediterranean storms. Adv. Geosciences 2, 13-19.

Nikulin G., Kjellström E., Hansson U., Strandberg G., Ullerstig A., 2011. Evaluation and future projections of temperature, precipitation and wind extremes over Europe in an ensemble of regional climate simulations. Tellus 63A, 41-55. doi 10.1111/j.1600-0870.2010.00466.x

Olsson J., Berggeren K., Olofsson M., Viklander M., 2009. Applying climate model precipitation scenarios for urban hydrological assessment: a case study in Kalmar City, Sweden. Atmos. Res. 92, 364-375. doi:10.1016/j.atmosres.2009.01.015

Onof C., Arnbjerg-Nielsen K., 2009. Quantification of anticipated future changes in high resolution design rainfall for urban areas. Atmos. Res. 92, 350-363. doi:10.1016/j.atmosres.2009.01.014

Orlowsky B., Seneviratne S., 2012. Global changes in extreme events: regional and seasonal dimensions. Clim. Change 110, 669-696.

Pal J.S., Giorgi F., Bi X., 2004. Consistency of recent European summer precipitation trends and extremes with future regional climate projections. Geophys. Res. Lett. 31, L13202 
Pinto J.G., Ulbrich U., Leckebusch G.C., Spangehl T., Reyers M., Zacharias S., 2007. Changes in storm track and cyclone activity in three SRES ensemble experiments with the ECHAM5/MPIOM1 GCM. Clim. Dyn. 29, 195-210.

Rao A.R., Hamed K.H., 1999. Flood frequency analysis. CRC Press, Boca Raton, Florida, USA.

Rodrigo F.S., 2010. Changes in the probability of extreme daily precipitation observed from 1951 to 2002 in the Iberian Peninsula. Int. J. Climatol. 30, 1512-1525.

Roeckner E., Bäuml G., Bonaventura L., Brokopf R., Esch M., Giorgetta M., Hagemann S., Kirchner I., Kornblueh L., Manzini E., Rhodin A., Schlese U., Schulzweida U., Tompkins A., 2003. The atmospheric general circulation model ECHAM 5. Part I: Model description. MPI Report No 349, Max Planck Institute for Meteorology, Hamburg.

Samuels R., Smiatek G., Krichak S., Kunstmann H., Alpert P., 2011. Extreme value indicators in highly resolved climate change simulations for the Jordan River area. J. Geophys. Res. 116, D24123, doi:10.1029/2011JD016322.

Samuelsson P., Gollvik S., Hansson U., Jones C., Kjellström E., Nikulin G., Ullerstig A., Willén U., Wyser K., 2011. The Rossby Centre regional climate model RCA3: Model description and performance. Tellus 63A, 4-23. doi: 10.1111/j.1600-0870.2010.00478.x

Sanchez-Gomez E., Somot S., Déque M., 2009. Ability of an ensemble of regional climate models to reproduce weather regimes over Europe-Atlantic during the period 1961-2000. Clim. Dyn. 33, 723-736. doi 10.1007/s00382-008-0502-7

Steppeler J., Doms G., Schättler U., Bitzer H.W., Gassmann A., Damrath U., Gregoric G., 2003. Meso-gamma scale forecasts using the nonhydrostatic model LM. Meteorol. Atm. Phys. 82, 7596.

Tramblay Y., Badi W., Driouech F., El Adlouni S., Neppel L., Servat E., 2012. Climate change impacts on extreme precipitation in Morocco. Global Planet. Change 82-83, 104-114.

Trenberth K.E., Dai A., Rasmussen R.M., Parsons D.B., 2003. The changing character of precipitation. Bull. Amer. Meteorol. Soc. 84, 1205-1217.

Ulbrich U., Leckebusch G.C., Pinto J.G., 2009. Extra-tropical cyclones in the present and future climate: a review. Theor. Appl. Climatol. 96, 117-131.

van der Linden P., Mitchell J.F.B. (eds.), 2009. ENSEMBLES: Climate Change and its Impacts: Summary of research and results from the ENSEMBLES project. Met Office Hadley Centre, FitzRoy Road, Exeter EX1 3PB, UK.

van Meijgaard E., van Ulft L.H., van de Berg W.J., Bosveld F.C., van den Hurk B.J.J.M., Lenderink G., Siebesma A.P., 2008. The KNMI regional atmospheric climate model RACMO, version 2.1. KNMI Tech Rep 302, R Neth Meteorol Inst, De Bilt, Netherlands. 
Table 1. RCMs examined in this study and their basic characteristics.

\begin{tabular}{|c|c|c|c|}
\hline RCM & Developed at & Description in & Driving GCM \\
\hline \multirow[t]{3}{*}{ HadRM3 } & $\begin{array}{l}\text { Met Office, Hadley Centre for } \\
\text { Climate Prediction and Research }\end{array}$ & Jones et al. (2004) & HadCM3Q0 $^{1)}$ \\
\hline & & & HadCM3Q3 \\
\hline & & & HadCM3Q16 \\
\hline CLM & $\begin{array}{l}\text { Swiss Institute of Technology } \\
\text { (ETHZ) }\end{array}$ & Steppeler et al. (2003) & HadCM3Q0 \\
\hline \multirow[t]{4}{*}{ RCA } & $\begin{array}{l}\text { Swedish Meteorological and } \\
\text { Hydrological Institute (SMHI) }\end{array}$ & Samuelsson et al. (2011) & $\mathrm{BCM}$ \\
\hline & & & ECHAM5-r3 \\
\hline & & & HadCM3Q3 \\
\hline & & & HadCM3Q16 \\
\hline HIRHAM & $\begin{array}{l}\text { Danish Meteorological Institute } \\
\text { (DMI) }\end{array}$ & Christensen et al. (1996) & ARPEGE \\
\hline RACMO & $\begin{array}{l}\text { The Royal Netherlands } \\
\text { Meteorological Institute (KNMI) }\end{array}$ & $\begin{array}{l}\text { van Meijgaard et al. } \\
(2008)\end{array}$ & ECHAM5-r3 \\
\hline $\mathrm{RegCM}$ & $\begin{array}{l}\text { Abdus Salam Int. Centre for } \\
\text { Theoretical Physics (ICTP) }\end{array}$ & Giorgi et al. (2004) & ECHAM5-r3 \\
\hline REMO & Max Planck Institute (MPI) & Jacob (2001) & ECHAM5-r3 \\
\hline
\end{tabular}

1) 3 ensemble members of HadCM3 with normal (Q0), low (Q3) and high (Q16) sensitivity 
Table 2. Ensemble-mean projected relative changes (2070-99 against 1961-90, in \%) in precipitation characteristics, averaged over the regions shown in Fig. 6. The largest relative change for mean seasonal maxima and 50-yr return precipitation of different durations is marked in bold.

a. Iberian Peninsula (land only)

\begin{tabular}{|l|c|c|c|c|c|c|c|c|c|}
\hline & Mean & \multicolumn{4}{|c|}{ Mean seasonal maxima } & \multicolumn{4}{c|}{50 -yr return precipitation } \\
\cline { 3 - 10 } & $\begin{array}{c}\text { seasonal } \\
\text { precipitation }\end{array}$ & $1 \mathrm{~h}$ & $1 \mathrm{~d}$ & $5 \mathrm{~d}$ & $15 \mathrm{~d}$ & $1 \mathrm{~h}$ & $1 \mathrm{~d}$ & $5 \mathrm{~d}$ & $15 \mathrm{~d}$ \\
\hline DJF & -0.2 & $\mathbf{7 . 7}$ & 4.2 & 2.9 & 2.2 & $\mathbf{2 8 . 2}$ & 16.6 & 11.8 & 11.1 \\
\hline MAM & -24.1 & $\mathbf{4 . 1}$ & -0.1 & -3.0 & -5.1 & $\mathbf{2 5 . 2}$ & 8.2 & -0.4 & -2.0 \\
\hline JJA & -41.0 & $\mathbf{- 2 . 3}$ & -5.7 & -7.7 & -9.6 & $\mathbf{5 . 8}$ & -5.3 & -14.7 & -21.7 \\
\hline SON & -18.2 & $\mathbf{4 . 4}$ & -0.5 & -2.3 & -3.7 & $\mathbf{2 8 . 1}$ & 15.6 & 8.5 & 8.1 \\
\hline
\end{tabular}

b1. Southern France (land only)

\begin{tabular}{|l|c|c|c|c|c|c|c|c|c|}
\hline & \multirow{2}{*}{$\begin{array}{c}\text { Mean } \\
\text { seasonal } \\
\text { precipitation }\end{array}$} & \multicolumn{4}{|c|}{ Mean seasonal maxima } & \multicolumn{4}{|c|}{50 -yr return precipitation } \\
\cline { 3 - 10 } & 8.5 & $1 \mathrm{~h}$ & $1 \mathrm{~d}$ & $5 \mathrm{~d}$ & $15 \mathrm{~d}$ & $1 \mathrm{~h}$ & $1 \mathrm{~d}$ & $5 \mathrm{~d}$ & $15 \mathrm{~d}$ \\
\hline DJF & -7.8 & $\mathbf{6 . 3}$ & 5.2 & 4.7 & 4.4 & $\mathbf{2 2 . 4}$ & 15.8 & 14.1 & 10.7 \\
\hline MAM & -28.5 & $\mathbf{3 . 2}$ & 1.4 & -0.5 & -2.1 & $\mathbf{1 9 . 0}$ & 14.8 & 6.8 & 1.5 \\
\hline JJA & -5.7 & $\mathbf{7 . 8}$ & 2.4 & -0.7 & -2.6 & $\mathbf{3 3 . 2}$ & 15.8 & 6.1 & 3.0 \\
\hline SON & & &
\end{tabular}

b2. Balearic Sea (ocean and land areas)

\begin{tabular}{|l|c|c|c|c|c|c|c|c|c|}
\hline & $\begin{array}{c}\text { Mean } \\
\text { seasonal } \\
\text { precipitation }\end{array}$ & \multicolumn{4}{|c|}{ Mean seasonal maxima } & \multicolumn{4}{|c|}{50 -yr return precipitation } \\
\cline { 3 - 10 } & -4.0 & $\mathbf{5 . 1}$ & 3.4 & 1.9 & 0.6 & $\mathbf{2 3 . 4}$ & 18.5 & 12.8 & 6.2 \\
\hline DJF & -18.8 & $\mathbf{3 . 3}$ & 1.4 & 0.2 & -0.5 & $\mathbf{1 8 . 2}$ & 8.4 & 1.1 & -0.5 \\
\hline MAM & -28.5 & $\mathbf{7 . 7}$ & 4.6 & 2.8 & 0.8 & $\mathbf{1 7 . 7}$ & 9.4 & 6.0 & -0.1 \\
\hline JJA & -10.7 & $\mathbf{3 . 9}$ & 1.1 & -1.0 & -2.1 & $\mathbf{3 5 . 7}$ & 27.7 & 20.7 & 13.7 \\
\hline SON & & &
\end{tabular}

c. Central Mediterranean (land only)

\begin{tabular}{|l|c|c|c|c|c|c|c|c|c|}
\hline & $\begin{array}{c}\text { Mean } \\
\text { seasonal } \\
\text { precipitation }\end{array}$ & \multicolumn{4}{|c|}{ Mean seasonal maxima } & \multicolumn{4}{|c|}{50 -yr return precipitation } \\
\cline { 3 - 10 } & 2.4 & $\mathbf{7 . 1}$ & 4.7 & 4.3 & 3.3 & $\mathbf{2 6 . 7}$ & 16.1 & 13.2 & 9.1 \\
\hline DJF & -14.4 & $\mathbf{4 . 6}$ & 2.9 & 0.7 & -1.7 & $\mathbf{2 2 . 6}$ & 14.3 & 8.5 & 2.5 \\
\hline MAM & -33.3 & $\mathbf{0 . 8}$ & -1.1 & -3.7 & -5.4 & $\mathbf{1 2 . 9}$ & 7.4 & 1.2 & -3.0 \\
\hline JJA & -6.4 & $\mathbf{9 . 3}$ & 5.7 & 2.8 & 2.1 & $\mathbf{3 5 . 2}$ & 21.7 & 12.8 & 9.5 \\
\hline SON & & &
\end{tabular}

d. Greece (land only)

\begin{tabular}{|l|c|c|c|c|c|c|c|c|c|}
\hline & \multirow{2}{*}{$\begin{array}{c}\text { Mean } \\
\text { seasonal } \\
\text { precipitation }\end{array}$} & \multicolumn{4}{|c|}{ Mean seasonal maxima } & \multicolumn{4}{c|}{50 -yr return precipitation } \\
\cline { 3 - 10 } & -6.5 & $\mathbf{4 . 7}$ & $1 \mathrm{~d}$ & $5 \mathrm{~d}$ & $15 \mathrm{~d}$ & $1 \mathrm{~h}$ & $1 \mathrm{~d}$ & $5 \mathrm{~d}$ & $15 \mathrm{~d}$ \\
\hline DJF & -21.1 & $\mathbf{4 . 9}$ & 2.4 & 0.7 & -0.1 & $\mathbf{2 0 . 5}$ & 16.9 & 10.4 & 5.5 \\
\hline MAM & -43.6 & $\mathbf{- 6 . 1}$ & -7.8 & -10.1 & -14.1 & $\mathbf{- 5 . 4}$ & -9.3 & -12.8 & -13.9 \\
\hline JJA & -12.0 & $\mathbf{9 . 1}$ & 5.7 & 3.4 & 2.2 & $\mathbf{3 2 . 8}$ & 20.4 & 10.6 & 8.6 \\
\hline SON & & &
\end{tabular}




\section{Figure captions}

Figure 1. Spatial patterns of mean seasonal precipitation and mean seasonal maxima of 1-day and 5-day precipitation amounts in the observed data (E-OBS, 1961-90) in individual seasons. Black dots denote those gridboxes in which maximum of a given precipitation characteristic occurs in a given season (i.e. for each gridbox and precipitation characteristic, black dot is plotted in just one season).

Figure 2. Same as in Fig. 1 but for ensemble-mean spatial patterns averaged over the 12 RCM simulations for the recent climate (1961-90).

Figure 3. Same as in Fig. 1 but for spatial patterns in individual RCM simulations for the recent climate (1961-90) in autumn (SON).

Figure 4. Ensemble-mean projected changes in mean seasonal precipitation and mean seasonal maxima of 1-hour to 15-day precipitation (relative changes in 2070-99 against 1961-90, in \%). Gridboxes in which at least 9 out of the 12 RCMs agree on a given sign of change are indicated by black dots.

Figure 5. Same as in Fig. 4 but for 50-yr return values of 1-hour to 15-day precipitation.

Figure 6. Regions for which ensemble-mean scenarios are evaluated in Table 2. The shaded areas correspond to gridboxes considered when calculating statistics in Table 2.

Figure 7. Ensemble-mean patterns and the interquartile range of the projected changes of 50yr return values of 1-hour precipitation in individual gridboxes (relative changes in 2070-99 against $1961-90$, in \%).

Figure 8. Same as in Fig. 7 but for 50-yr return values of 5-day precipitation.

Figure 9. Projected changes in mean seasonal precipitation and mean seasonal maxima of 1hour to 15-day precipitation (relative changes for 2070-99 against 1961-90, in \%) in individual RCMs in autumn (SON). Black dots denote those gridboxes in which the estimated $90 \%$ CIs do not overlap, i.e. the change is statistically significant approximately at $\mathrm{p}=0.01$.

Figure 10. Box-plots of projected relative changes (for 2070-99 against 1961-90) in autumn precipitation characteristics: mean seasonal precipitation (left), mean seasonal maxima (MAX) of 1-hour and 5-day precipitation (middle), and 50-yr return values (50y) of 1-hour and 5-day precipitation (right), averaged over 5 regions (a, b1, b2, c and d) shown in Fig. 6. 

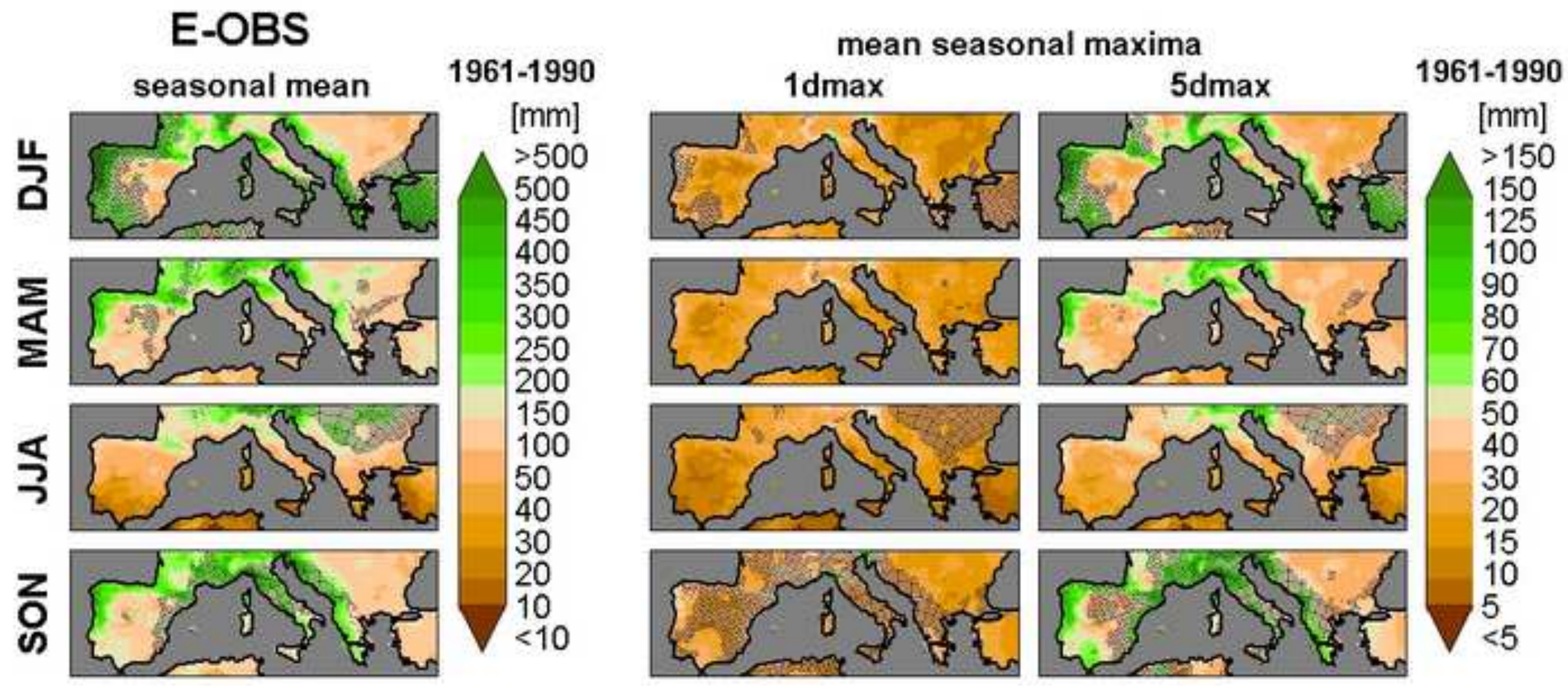
RCMs

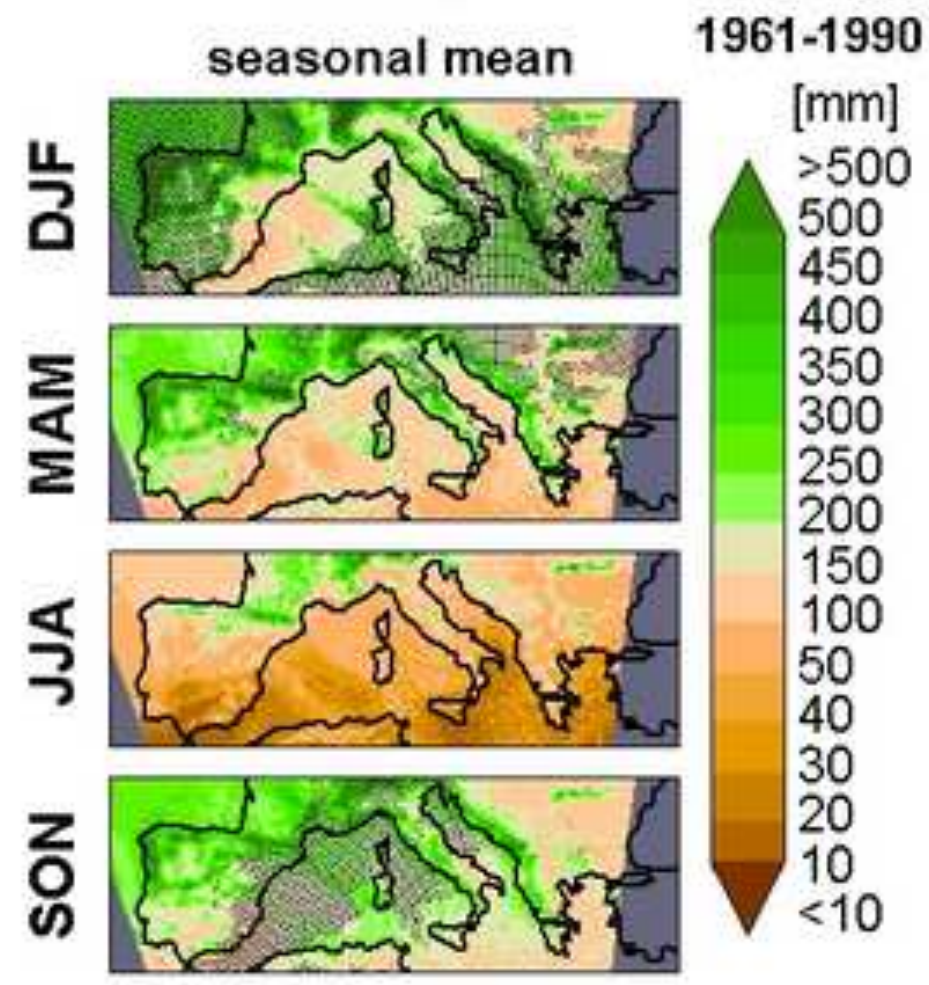

mean seasonal maxima
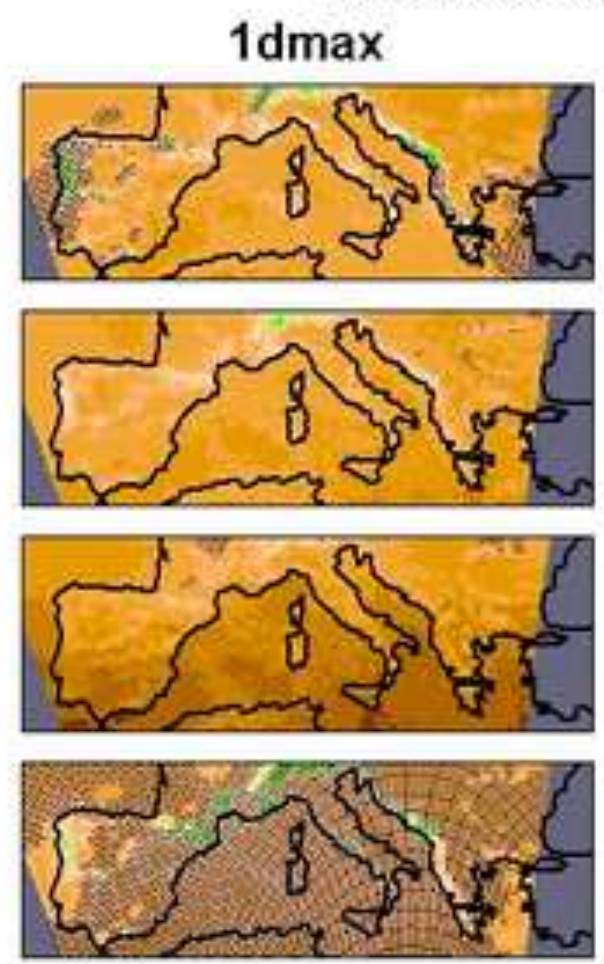

5dmax
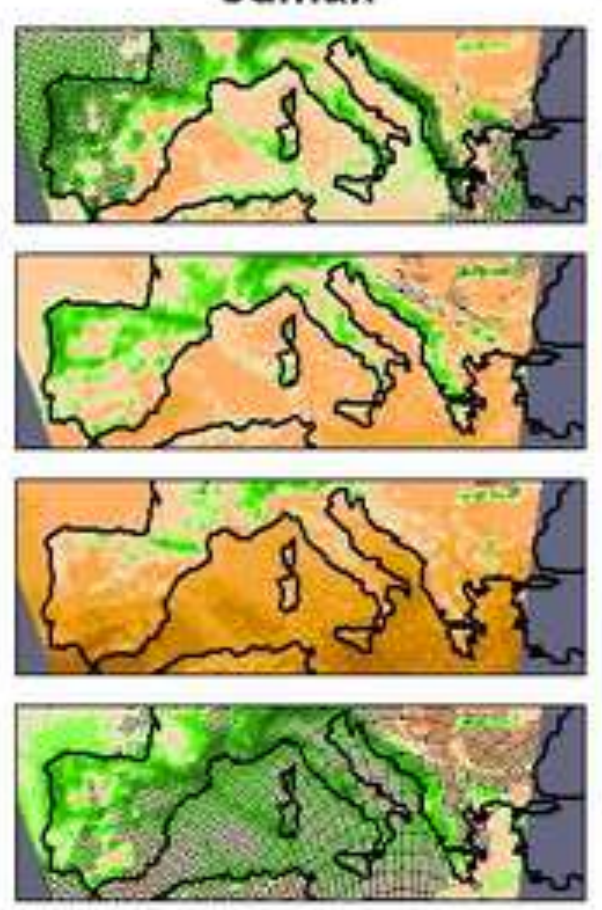

1961-1990

[mm]

$>150$
150
125
100
90
80
70
60
50
40
30
20
15
10
5
$<5$




\section{Figure 3}

Click here to download high resolution image
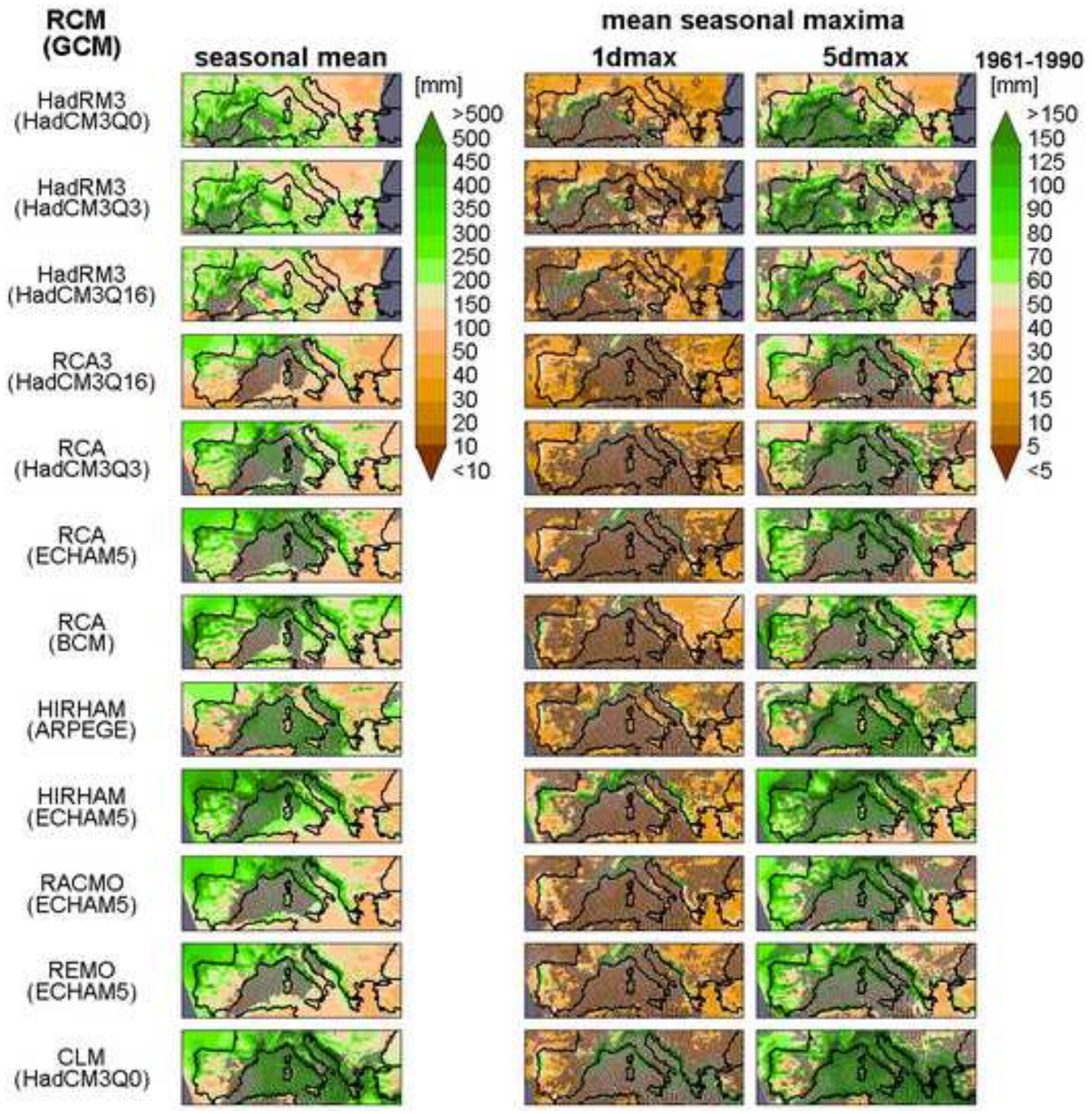
Click here to download high resolution image

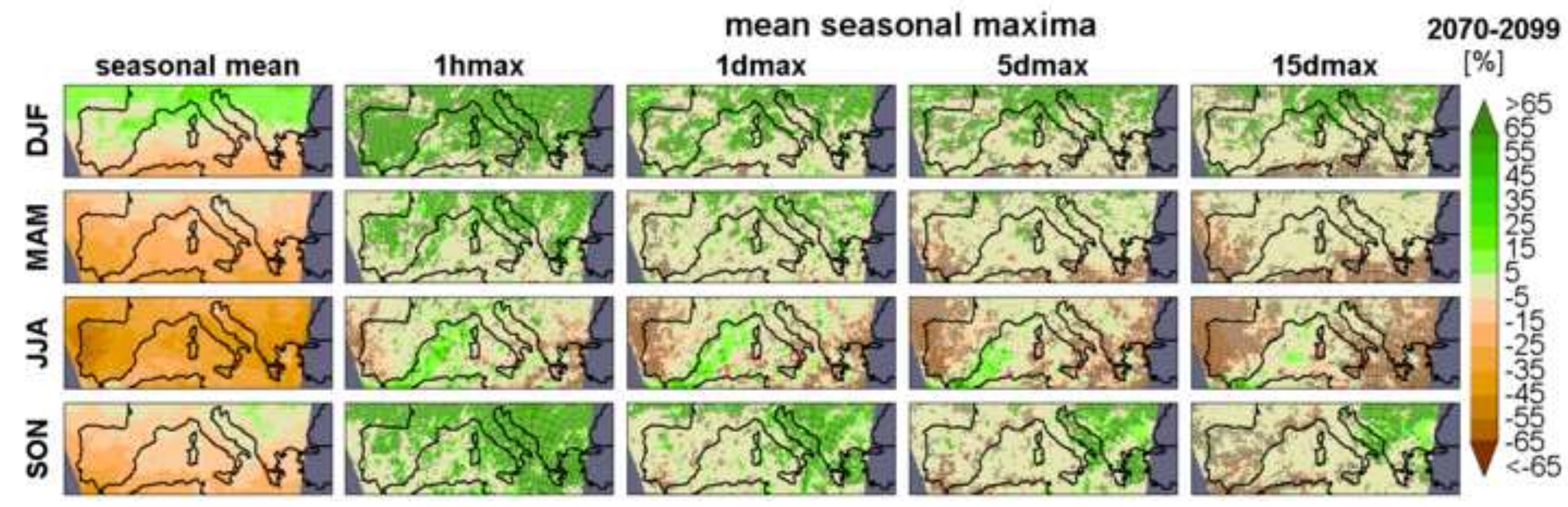

mean seasonal maxima 5 dmax 15dmax

[\%] 
Click here to download high resolution image

50 -yr return values

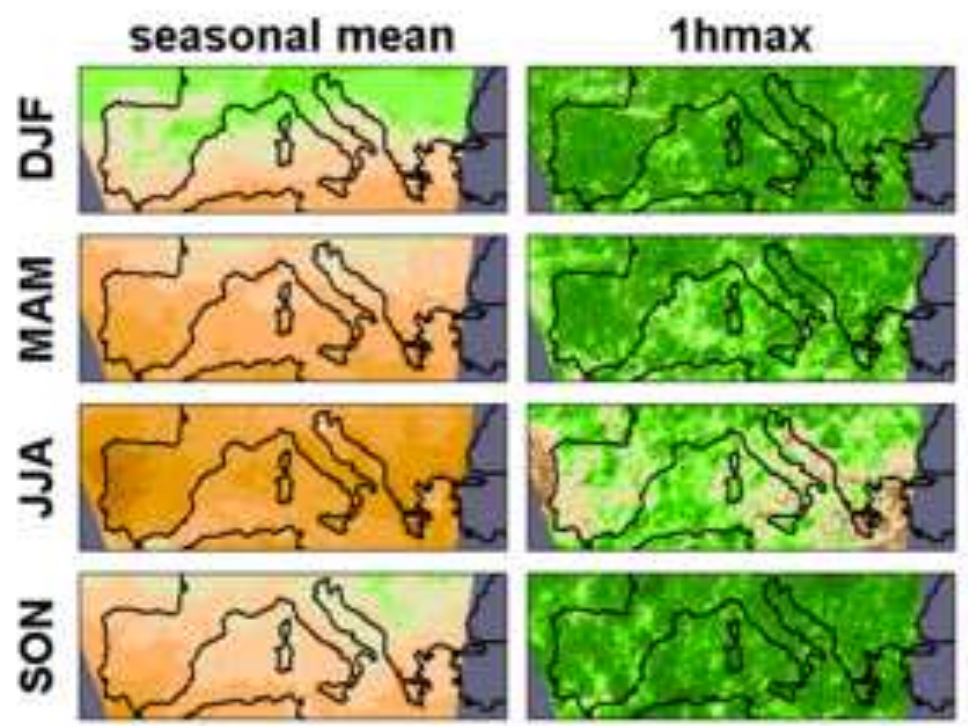

1 dmax

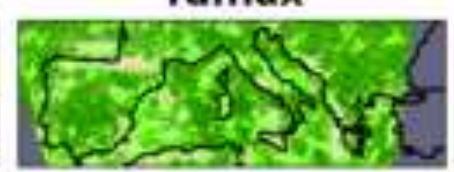

Gaser.
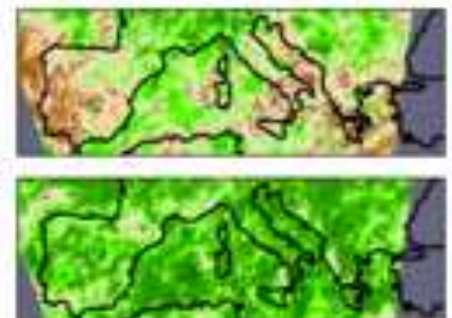

2070-2099

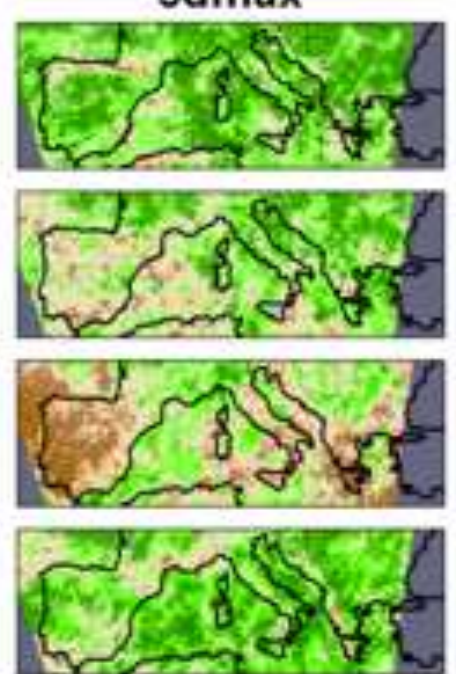

15dmax

[\%]

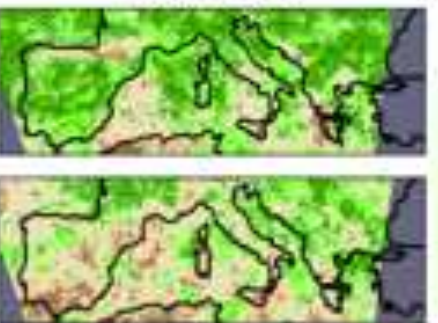

$>65$

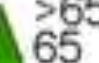

55

35

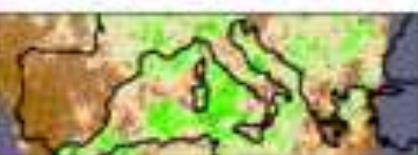

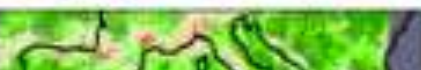

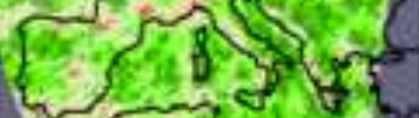




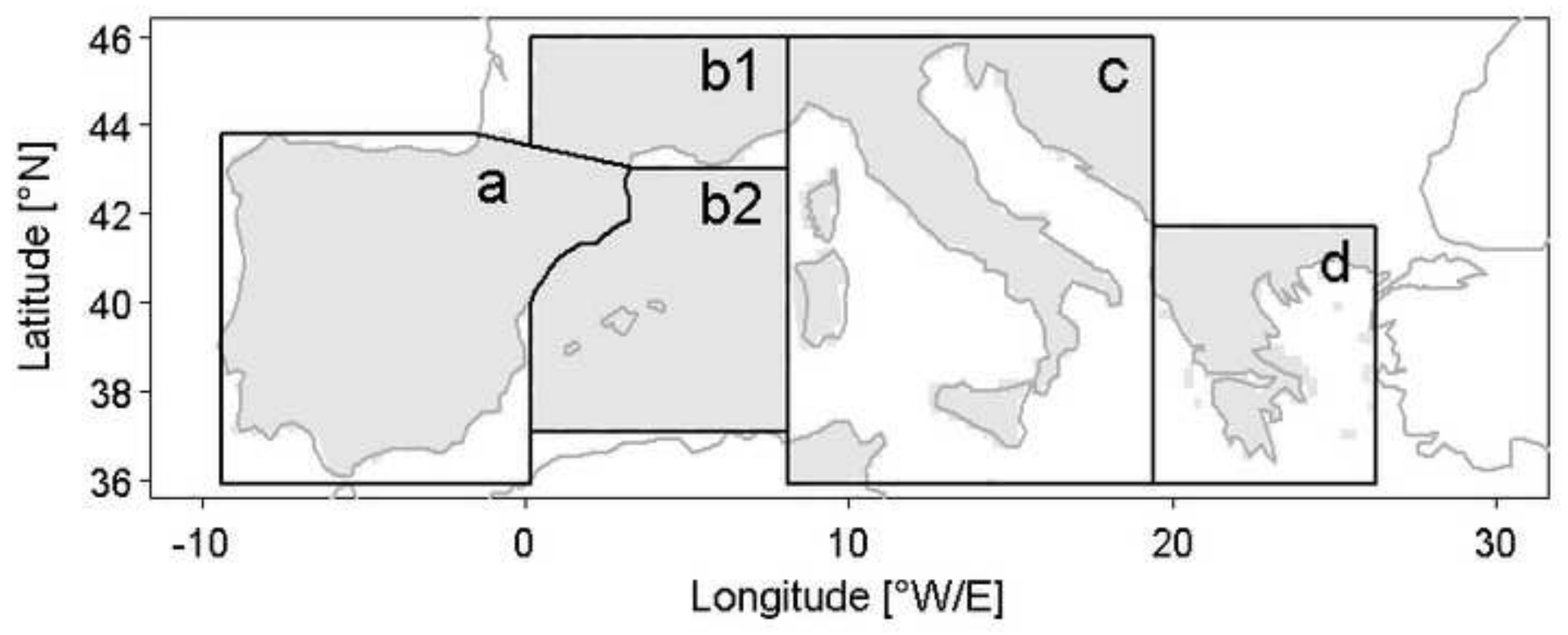


50 -yr return values of $1 \mathrm{~h}$ precipitation
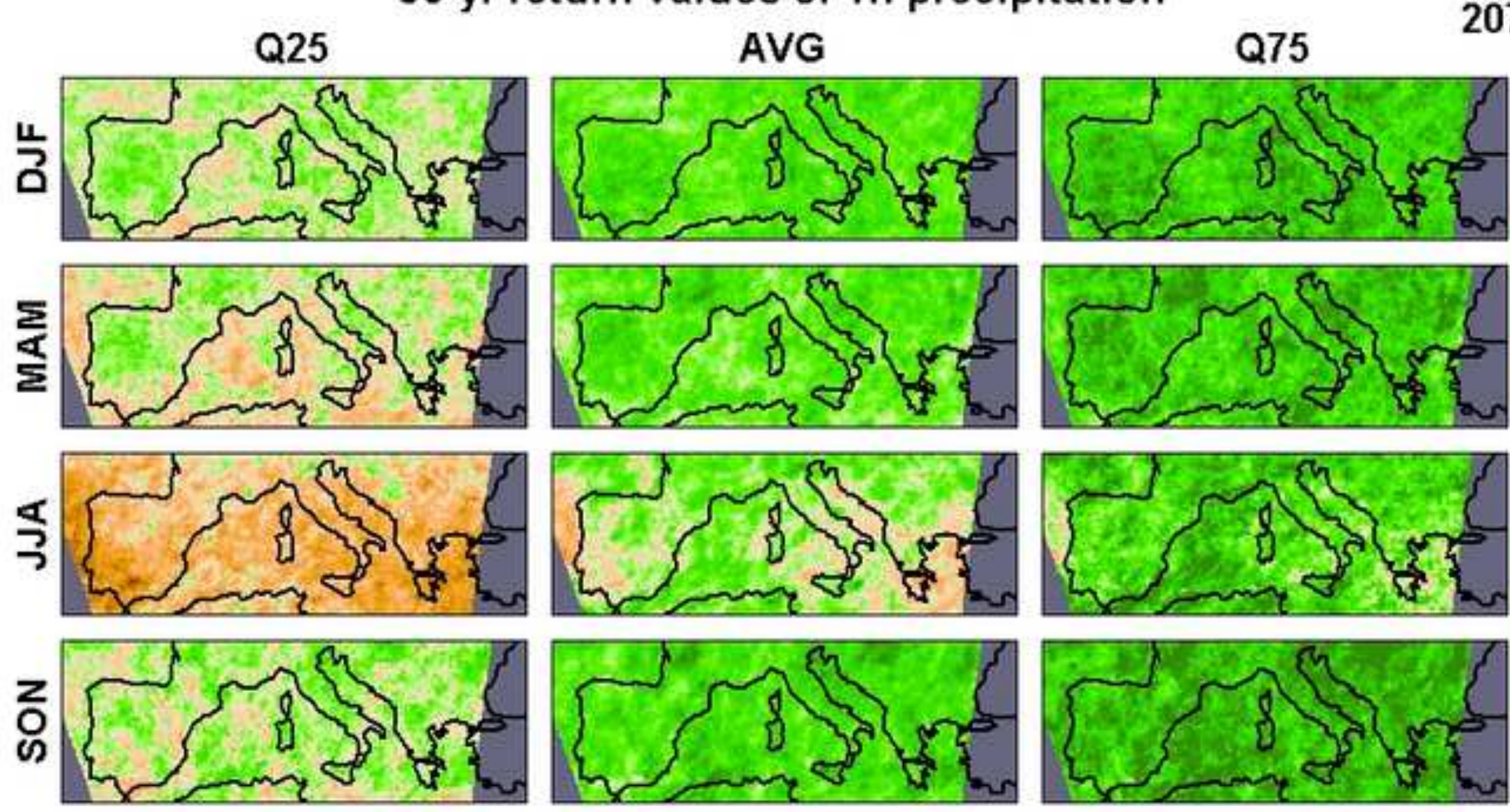

2070-2099

[\%]
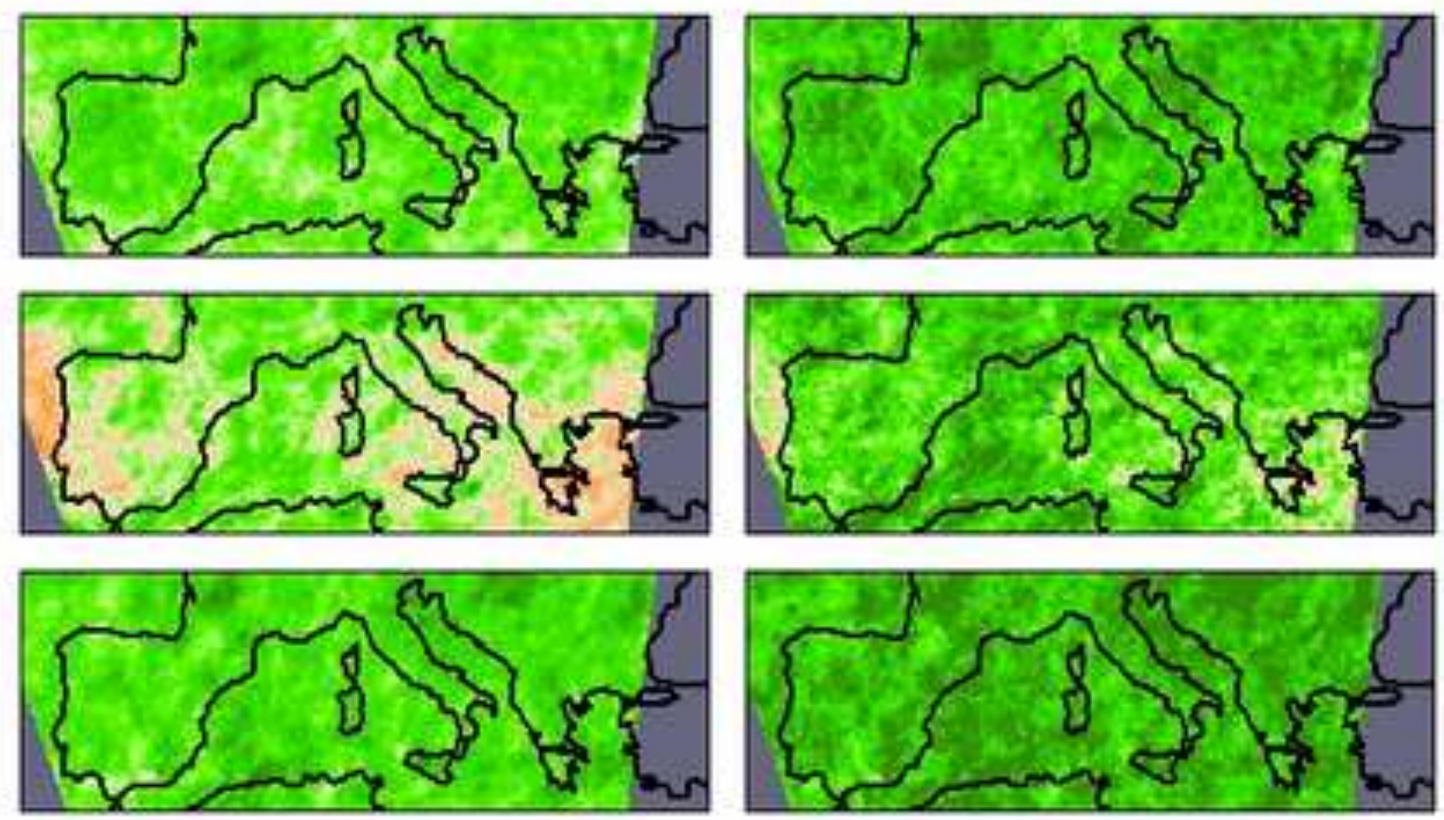

$>65$
65
55
45
35
25
15
5
-5
-15
-25
-35
-45
-55
-65
$<-65$


50-yr return values of $5 \mathrm{~d}$ precipitation
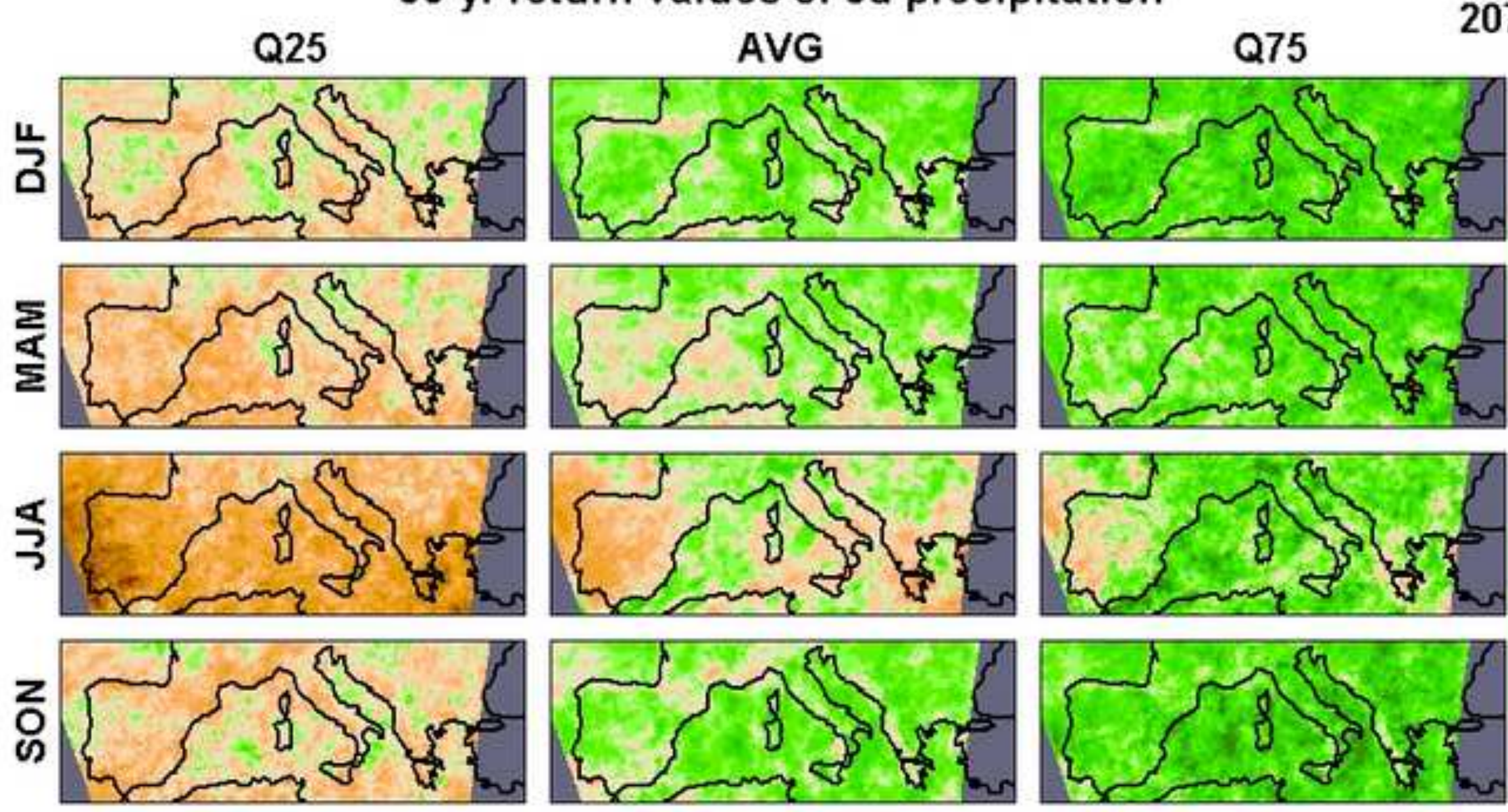

2070-2099

[\%]
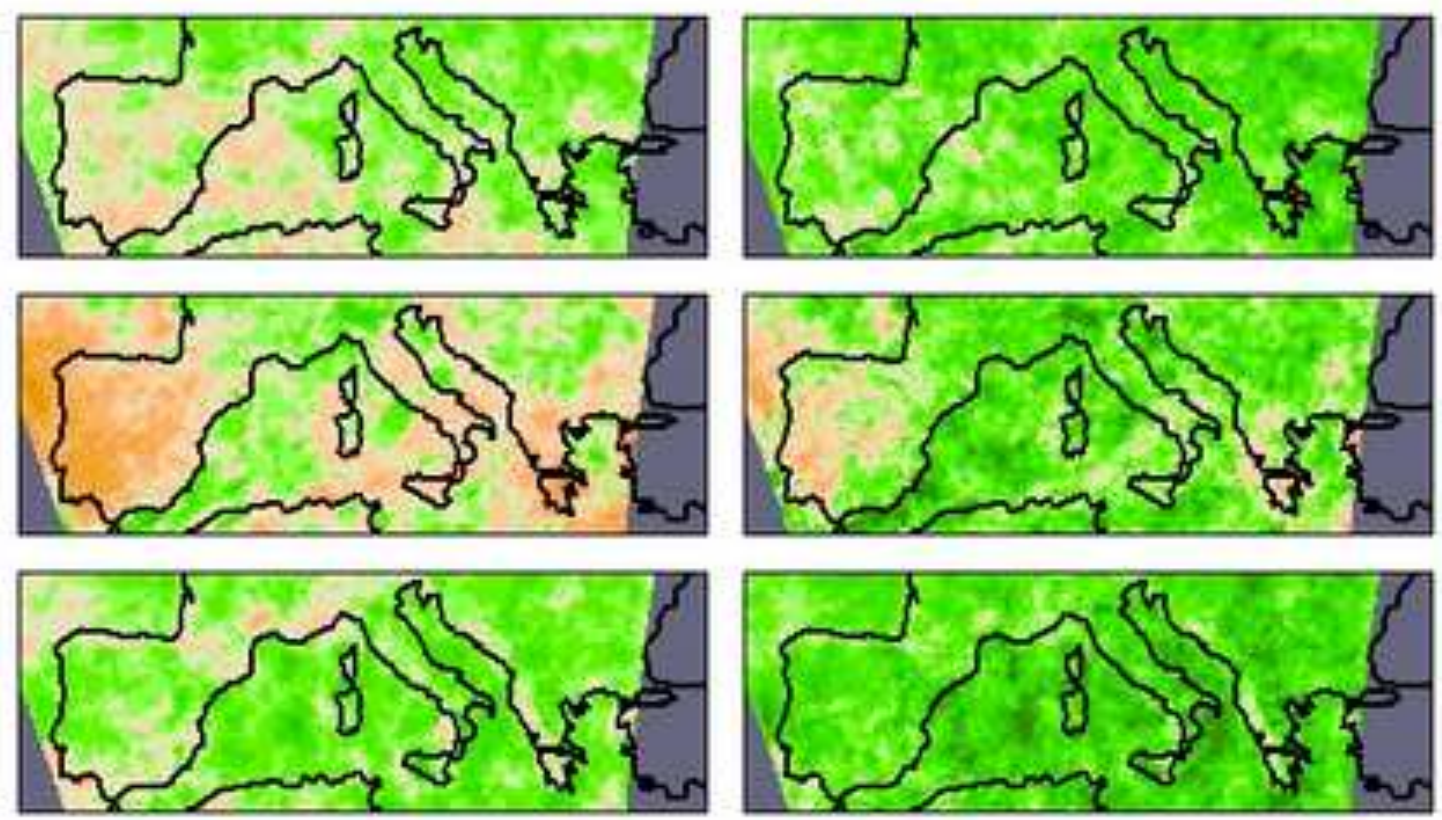

$>65$
65
55
45
35
25
15
5
-5
-15
-25
-35
-45
-55
-65
$<-65$


Figure 9

Click here to download high resolution image

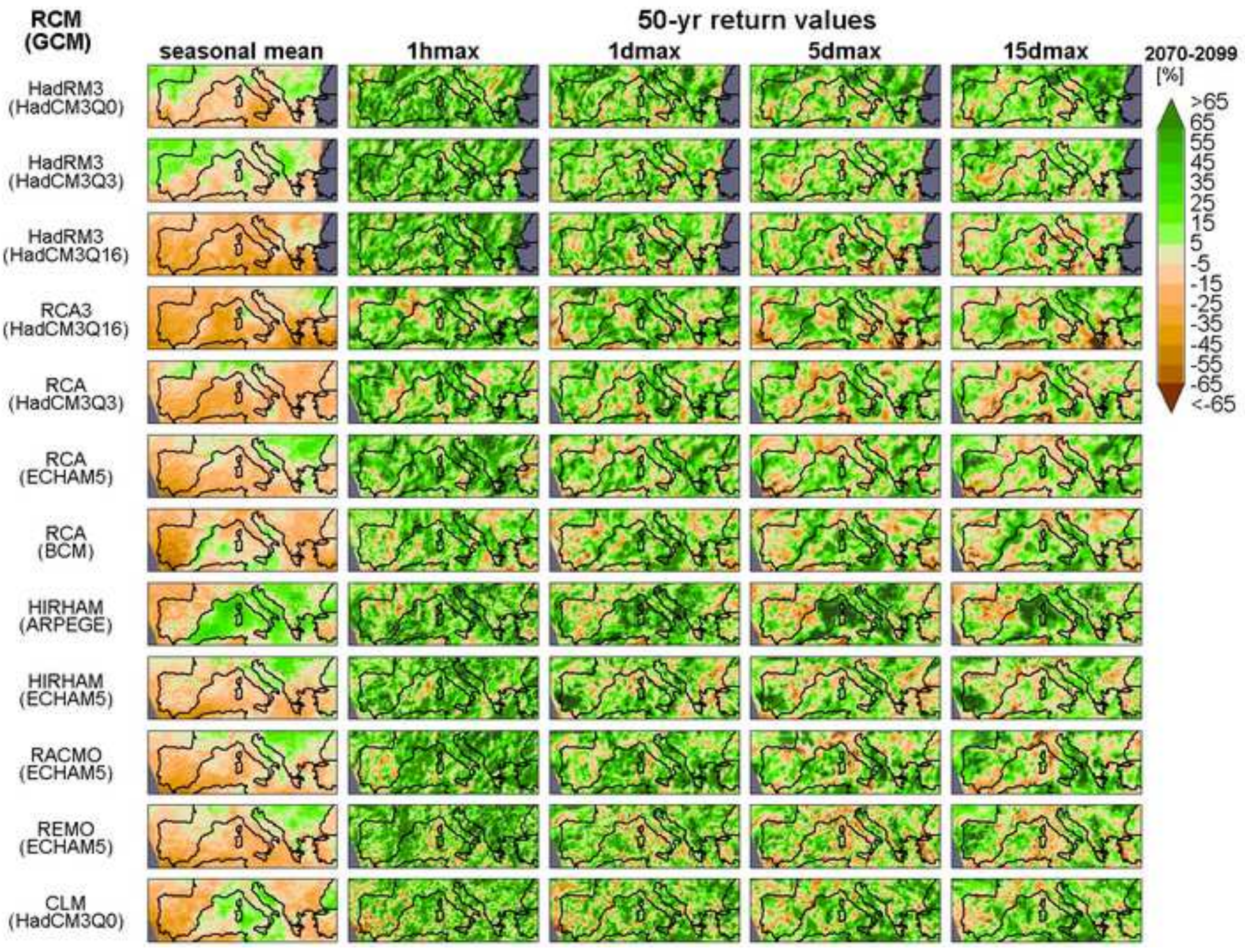




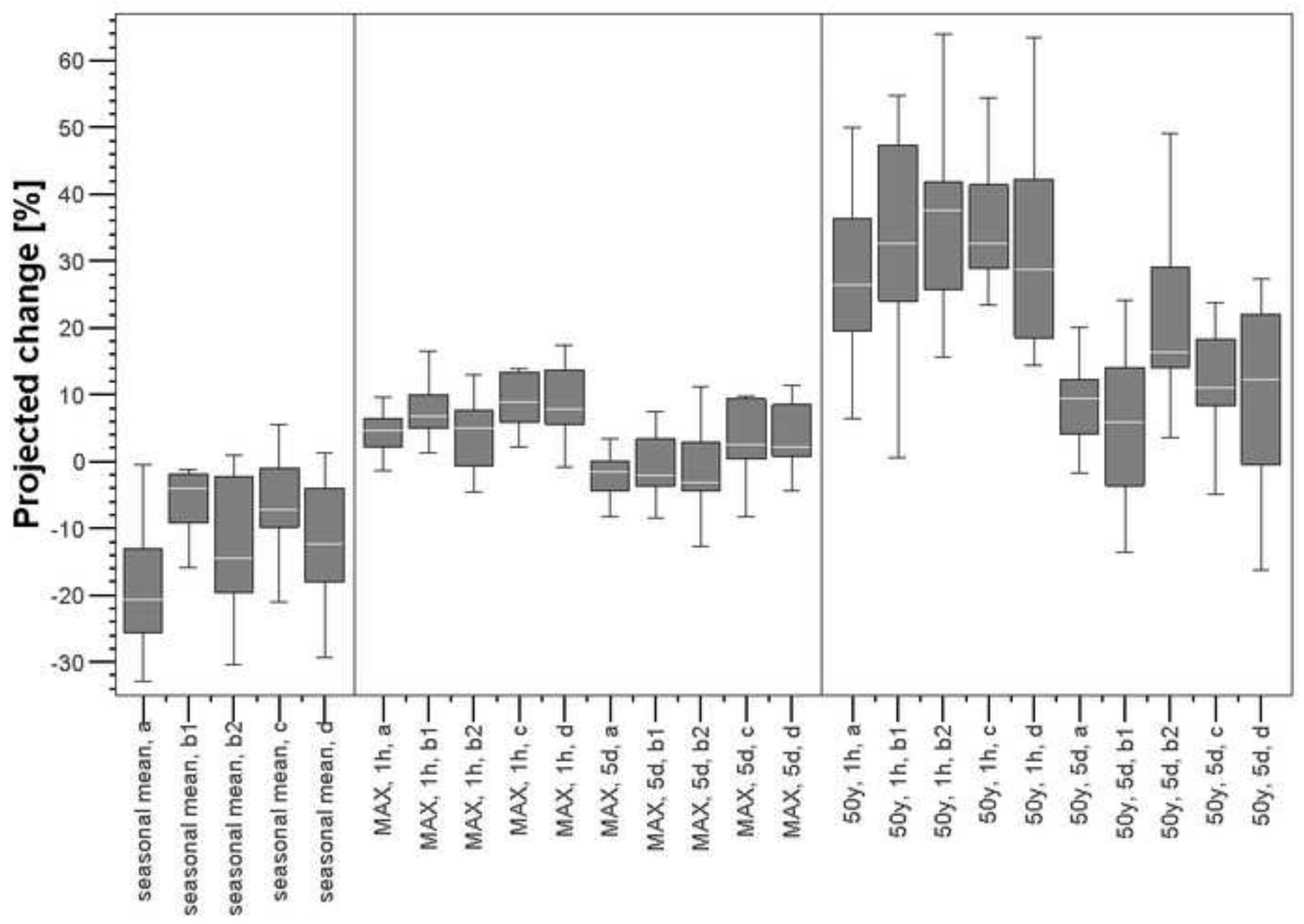

